\title{
Serum ferritin levels in adults with sickle cell disease in Lagos, Nigeria
}

This article was published in the following Dove Press journal:

Journal of Blood Medicine

2I May 2013

Number of times this article has been viewed

\section{Akinsegun A Akinbami' \\ Adedoyin O Dosunmu' \\ Adewumi A Adediran ${ }^{3}$ \\ Olajumoke $O$ Oshinaike ${ }^{2}$ \\ Vincent $O$ Osunkalu' \\ Sarah O Ajibola ${ }^{3}$ \\ Olanrewaju M Arogundade'}

'Department of Haematology and Blood Transfusion, ${ }^{2}$ Department of Medicine, Lagos State University, College of Medicine, Ikeja, Nigeria;

${ }^{3}$ Department of Haematology and Blood Transfusion, Faculty of Clinical Sciences, College of Medicine, Idiaraba, Nigeria
Correspondence: Akinsegun A Akinbami Department of Haematology and Blood Transfusion, Lagos State University, College of Medicine, Ikeja, Nigeria Tel 23418023064925

Email ajoke_clinic@yahoo.co.uk
Background: Serum ferritin is considered to be one of the most important tools in the measurement of iron balance in steady-state sickle cell disease. Increased gastrointestinal absorption of iron has been reported in sickle cell disease because of the associated chronic hemolysis, and it is also thought that repeated red cell transfusion consequent to chronic hemolysis and anemia causes excessive iron levels. The aim of this study was to determine overall and gender-specific mean ferritin levels in patients with steady-state sickle cell disease in order to establish the prevalence of iron deficiency and overload.

Methods: This was a cross-sectional study in homozygous patients with sickle cell disease attending the sickle cell clinic at Lagos State University Teaching Hospital, Ikeja. A $5 \mathrm{~mL}$ blood sample was collected in plain bottles from consenting participants during steady-state periods. The serum was separated and analyzed for ferritin by enzyme-linked immunosorbent assay. Another $5 \mathrm{~mL}$ sample was collected for a full blood count, done on the same day of collection, to determine red blood cell indices, ie, mean cell volume, mean cell hemoglobin concentration, and mean corpuscular hemoglobin concentration. The Pearson Chi-square test was used for statistical analysis. The differences were considered to be statistically significant when $P$ was $<0.05$.

Results: In total, 103 patients were recruited for this study and comprised 58 women $(56.40 \%)$ and 45 men (43.70\%). The overall mean ferritin concentration was $93.72 \pm 92.24 \mathrm{ng} / \mathrm{mL}$. The mean ferritin concentration in the women was $92.00 \pm 88.07 \mathrm{ng} / \mathrm{mL}$ and in men was $96.41 \pm 99.80 \mathrm{ng} / \mathrm{mL}$. Only eight (7.76\%) of the 103 patients had a serum ferritin level $<15 \mathrm{ng} / \mathrm{mL}$, while two subjects $(1.94 \%$ ) had a serum a ferritin level $>300 \mathrm{ng} / \mathrm{mL}$. Ninety-three subjects (90.29\%) had serum ferritin within the normal reference range of $15-300 \mathrm{ng} / \mathrm{mL}$.

Conclusion: In this study, $90 \%$ of subjects with sickle cell disease had normal iron stores; serum ferritin was higher in men than in women, and iron deficiency was more common than overload in the disease.

Keywords: serum ferritin levels, sickle cell disease

\section{Introduction}

Sickle cell disease results from an inherited abnormality of hemoglobin structure. The abnormal hemoglobin has valine replacing glutamine at position 6 of the beta-globin chain. ${ }^{1}$ The hemoglobin variant produced polymerizes at low oxygen tension, causing the characteristic sickle deformity of red blood cells, increased mechanical fragility, shortened survival, and chronic hemolytic anemia. ${ }^{2}$

The normal iron level in men is $50 \mathrm{mg} / \mathrm{kg}$ and $40 \mathrm{mg} / \mathrm{kg}$ in women, and the normal serum ferritin range is $15-300 \mu \mathrm{g} / \mathrm{L}$, being higher in men (mean $100 \mu \mathrm{g} / \mathrm{L}$ ) than in premenopausal women (mean $30 \mu \mathrm{g} / \mathrm{L}$ ). ${ }^{3}$ Ferritin is the primary iron storage protein in 
tissues, and ferritin is also an acute phase reactant, with elevated serum levels in the presence of chronic inflammation, infection, and liver disorders associated with sickle cell disease in crisis. In the absence of deranged iron status, conventional laboratory assessments of iron status, such as mean cell volume, mean cell hemoglobin, mean corpuscular hemoglobin concentration, and red cell distribution width, may be abnormal in patients with sickle cell disease due to the chronic inflammation and hemolysis associated with the disease. ${ }^{4,5}$

It is also difficult to quantify the contribution of iron deficiency to anemia in chronic inflammatory conditions. This is especially true in conditions such as sickle cell disease where proinflammatory cytokines may induce an anemia of inflammation and alter the biochemical indicators of iron status commonly used to diagnose iron deficiency. ${ }^{6,7}$ Despite all these limitations, and in the absence of other pathology, serum ferritin is generally a reliable indicator of the presence of iron overload. ${ }^{3}$ Serum ferritin is also considered one of the most important tools in measurement of the state of iron balance in steady-state sickle cell disease. ${ }^{8}$ In the event of increased gastrointestinal absorption of iron due to chronic hemolysis associated with sickle cell disease, ${ }^{9}$ it is also expected that repeated red cell transfusions consequent to chronic hemolysis and anemia leads to excessive iron levels. ${ }^{10}$ Several studies have reported iron overload in sickle cell disease. ${ }^{11-13}$ However, other studies have reported iron deficiency in sickle cell disease, ${ }^{10,14}$ despite the risk of increased gastrointestinal absorption. This study aimed to determine both overall and gender-specific mean serum ferritin levels in patients with steady-state sickle cell disease in order to establish the prevalence of iron deficiency and overload in steady state.

\section{Materials and methods}

This was a cross-sectional study in homozygous patients with sickle cell disease attending the sickle cell clinic of Lagos State University Teaching Hospital, Ikeja, between October and December 2011. Approval for the study was obtained from the research and ethics committee at the hospital. Consenting participants were helped to complete a structured questionnaire, consisting of demographic information, history of smoking, consumption of alcohol, drug use apart from the usual routine medications for sickle cell disease, history of blood transfusion, and frequency of bone pain crises. Inclusion criteria were hemoglobin phenotype SS, no history of crises in the previous three months as established by a careful history and complete physical examination, no previous history of surgery, and no history of blood transfusion in the previous three months. Exclusion criteria were a history of blood transfusion in the past three months, hemoglobin phenotype SC, previous history of surgery, and human immunodeficiency virus infection. Treatment with hydroxyurea is not a routine and standard practice at the center where the study was carried out. Participants were routinely treated with folic acid, vitamin B complex, and paludrine.

\section{Collection of samples}

A $5 \mathrm{~mL}$ blood sample was collected from each subject into a nonanticoagulated bottle during a period of steady state. The serum was separated and stored at $-20^{\circ} \mathrm{C}$ on the day of collection until analysis for ferritin. Another $5 \mathrm{~mL}$ sample was collected from each subject for a full blood count, done on the same day of collection, to determine mean cell volume, mean cell hemoglobin, and mean corpuscular hemoglobin concentration.

\section{Testing}

An enzyme-linked immunosorbent assay kit (Biotec Laboratories Ltd, Ipswich, UK) was used for determination of ferritin. After incubation, bound/free separation was performed by simple solid-phase washing. The ferritin concentration in the sample was calculated based on a standard curve. The kit has a control and six standards $\left(\mathrm{S}_{1}-\mathrm{S}_{5}\right)$ with concentrations of $0,5,20,100,400$, and $1000 \mathrm{ng} / \mathrm{mL}$, respectively. The standards were calibrated against the World Health Organization Human Liver Ferritin International Standard 80/602. Assay of the control, standards, samples, and blanks was performed in duplicate, using the mean value for each parameter. Values of the absorbance of the standards against concentration were plotted to obtain a standard curve using the best-fit points. Absorbance values for the samples were interpolated on the standard curve to obtain the corresponding concentrations expressed in $\mathrm{ng} / \mathrm{mL}$. The mean reference values and ranges quoted by the manufacturer are $53 \mathrm{ng} / \mathrm{mL}$; 6-180 ng/mL and $175 ; 20-400 \mathrm{ng} / \mathrm{mL}$ for both premenopausal women, and men, respectively.

\section{Analysis of data}

The descriptive data are shown as the mean \pm standard deviation. The Pearson chi-square test and $t$-test were used for analytical assessment. The differences were considered to be statistically significant at $P<0.05$.

\section{Results}

In total, 103 patients were recruited for the study, comprising $58(56.40 \%)$ women and $45(43.70 \%)$ men. The mean age for 
the entire group was $24.08 \pm 7.84$ (range 14-144) years. The mean age for the women was $25.13 \pm 8.47$ years and for the men was $22.82 \pm 6.89$ years. The majority $(77,74.8 \%)$ had previously received blood transfusions, while 26 (25.2\%) gave no history of blood transfusion (Table 1).

Overall mean hemoglobin, cell volume, cell hemoglobin, and corpuscular hemoglobin concentrations were $7.92 \pm 1.49 \mathrm{~g} / \mathrm{dL}, 80.32 \pm 11.30 \mathrm{fl}, 26.40 \pm 3.19 \mathrm{pg}$, and $32.42 \pm 1.05 \mathrm{~g} / \mathrm{dL}$, respectively. The minimum and maximum hemoglobin concentrations were $4.6 \mathrm{~g} / \mathrm{dL}$ and $11.8 \mathrm{~g} / \mathrm{dL}$, respectively; the minimum mean cell volume, mean cell hemoglobin, and mean corpuscular hemoglobin concentration values were $62.9 \mathrm{fl}, 16.5 \mathrm{pg}$, and $29.9 \mathrm{~g} / \mathrm{dL}$, respectively, and the maximum values were $103.0 \mathrm{fl}, 34.30 \mathrm{pg}$, and $34.40 \mathrm{~g} / \mathrm{dL}$, respectively. Mean hemoglobin, cell volume, cell hemoglobin, and corpuscular hemoglobin concentration values for men were $8.11 \pm 1.53 \mathrm{~g} / \mathrm{dL}, 81.80 \pm 14.12 \mathrm{fl}, 26.56 \pm 3.70 \mathrm{pg}$, and $32.44 \pm 1.01 \mathrm{~g} / \mathrm{dL}$, respectively; and for women were $7.78 \pm 1.42 \mathrm{~g} / \mathrm{dL}, 79.09 \pm 6.39 \mathrm{fl}, 26.27 \pm 2.48 \mathrm{pg}$, and $32.41 \pm 1.10 \mathrm{~g} / \mathrm{dL}$, respectively (Table 1 ).

The overall mean ferritin concentration was $93.72 \pm 92.24 \mathrm{ng} / \mathrm{mL}$, the minimum was $5 \mathrm{ng} / \mathrm{mL}$, and the maximum was $480 \mathrm{ng} / \mathrm{mL}$. The mean ferritin concentration for women was $92.00 \pm 88.07 \mathrm{ng} / \mathrm{mL}$ and for men was $96.41 \pm 99.80 \mathrm{ng} / \mathrm{mL}$. The minimum ferritin concentration for women was $5 \mathrm{ng} / \mathrm{mL}$ and the maximum was $430 \mathrm{ng} / \mathrm{mL}$. The minimum for men was $10 \mathrm{ng} / \mathrm{mL}$ and the maximum was $480 \mathrm{ng} / \mathrm{mL}$. The difference in mean ferritin concentration between men and women was not statistically significant using the unpaired $t$-test $(0.24, P=0.81$, Table 2$)$. The mean ferritin concentration of subjects who had a history of blood transfusion was $91.72 \pm 98.21 \mathrm{ng} / \mathrm{mL}$ and for those who had not been previously transfused was $100.83 \pm 68.75 \mathrm{ng} / \mathrm{mL}$. This was also not statistically significant $(P=0.662, t$-test $=0.44$, Table 2). Only eight (7.76\%) of the 103 patients had serum ferritin $<15 \mathrm{ng} / \mathrm{mL}$. While the majority $(95,92.23 \%)$ had serum ferritin $>15 \mathrm{ng} / \mathrm{mL}$, only two (1.94\%) had serum ferritin $>300 \mathrm{ng} / \mathrm{mL}$. In total, 93 (90.29\%) had serum ferritin within the normal reference range of 15-300 ng/mL (Table 1).

No statistically significant relationship was found between hemoglobin and corresponding ferritin concentration $(P=0.877)$, nor between patient age and ferritin concentration $(P=0.187$, Table 1$)$.

\section{Discussion}

Blood transfusion in patients with sickle cell anemia serves two major functions, ie, increasing the oxygen-carrying capacity of the blood ${ }^{15}$ and replacing abnormal red cells with normal ones, thereby alleviating symptoms and preventing complications. ${ }^{16,17}$ Over $70 \%$ of the patients recruited for this study had a previous history of blood transfusion. This highlights the fact that the practice of blood transfusion is common in the sickle cell anemia population, and almost all adult patients may have had multiple transfusions. However, this study did not show a statistically significant correlation between previous history of blood transfusion and ferritin concentration.

Table I Demographic distribution, history of blood transfusion, red blood cell indices, and ferritin levels

\begin{tabular}{|c|c|c|c|c|}
\hline & \multicolumn{4}{|l|}{ Gender } \\
\hline & Male & Female & Total & \\
\hline & $58(56.40 \%)$ & 45 (43.70\%) & 103 (100\%) & \\
\hline Mean age (years) & $22.82 \pm 6.89$ & $25.13 \pm 8.47$ & & \\
\hline \multirow[t]{2}{*}{ Previous history of blood transfusion } & Yes & No & & \\
\hline & 77 (74.8\%) & $26(25.2 \%)$ & & \\
\hline \multirow[t]{2}{*}{ Red blood cell indices } & \multirow[t]{2}{*}{ Minimum } & \multirow[t]{2}{*}{ Maximum } & \multicolumn{2}{|l|}{ Mean } \\
\hline & & & Male & Female \\
\hline Hemoglobin concentration & 4.6 & 11.8 & $8.11 \pm 1.53$ & $7.78 \pm 1.42$ \\
\hline Mean cell volume (femtoliter) & 62.9 & 103.0 & $81.80 \pm 14.12$ & $79.09 \pm 6.39$ \\
\hline Mean cell hemoglobin (picogram) & 16.5 & 34.30 & $26.56 \pm 3.70$ & $26.27 \pm 2.48$ \\
\hline Mean cell hemoglobin concentration $(\mathrm{g} / \mathrm{dL})$ & 29.9 & 34.40 & $32.44 \pm 1.01$ & $32.41 \pm 1.10$ \\
\hline Ferritin concentration levels & Male & Female & & \\
\hline Mean \pm standard deviation $(\mathrm{ng} / \mathrm{mL})$ & $96.41 \pm 99.80$ & $92.00 \pm 88.07$ & & \\
\hline I5-300 ng/mL & $93(90.29 \%)$ & & & \\
\hline$<15 \mathrm{ng} / \mathrm{mL}$ & $8(7.76 \%)$ & & & \\
\hline$>300 \mathrm{ng} / \mathrm{mL}$ & $2(1.94 \%)$ & & & \\
\hline Hemoglobin versus ferritin levels & $P=0.877$ & & & \\
\hline Age versus ferritin levels & $P=0.187$ & & & \\
\hline
\end{tabular}


Table 2 Correlation between mean ferritin concentration, gender, and history of blood transfusion

\begin{tabular}{lllll}
\hline Parameters & $\mathbf{n}$ & Mean ferritin & $\boldsymbol{P}$ value & $\boldsymbol{t}$-test \\
\hline Male & 45 & $96.41 \pm 99.80$ & 0.812 & 0.24 \\
Female & 58 & $92.00 \pm 88.07$ & & \\
& Yes & No & $\boldsymbol{P}$ value & $\boldsymbol{t}$-test \\
\hline Blood transfusion & 77 & 22 & 0.662 & 0.44 \\
Mean ferritin & $91.72 \pm 98.21$ & $100.83 \pm 68.75$ & & \\
\hline
\end{tabular}

Mean cell volume, mean cell hemoglobin, and mean cell hemoglobin concentration are all reduced in anemia of chronic disease. Expectedly, in this study, mean hemoglobin concentration, mean cell volume, and mean cell hemoglobin were higher in men than in women. Increased erythropoiesis due to androgens in males, and iron loss or blood loss in females during menstruation may be responsible for higher levels of the red cell indices in males. However, reference ranges for erythropoietin are not different between the men and women. ${ }^{18}$

The mean ferritin concentration obtained for women was much higher than the nonsickle cell value quoted by the manufacturer of the kit used for the study. However, a lower value was obtained in the men. As expected, the mean ferritin value obtained in this study was higher in men than in women. ${ }^{3}$

The majority (90\%) of the patients had serum ferritin within the normal reference range of $15-300 \mathrm{ng} / \mathrm{mL}$. This was an unexpected result, given that over $70 \%$ of the patients recruited for this study had a previous history of blood transfusion, and also considering that, given the high rate of chronic hemolysis seen in patients with sickle cell disease, increased gastrointestinal absorption of iron due to chronic hemolysis would have been expected. ${ }^{9}$ It has been shown that repeated red blood cell transfusion consequent to chronic hemolysis and anemia provides excessive iron levels and ferritin values above the normal reference range. ${ }^{10}$ This study reported only about $2 \%$ of patients with a ferritin concentration above the normal reference range of $300 \mathrm{ng} / \mathrm{mL}$, while $7.76 \%$ had ferritin levels below the lower limit of the normal reference range $(15 \mathrm{ng} / \mathrm{mL})$. A similar result was obtained by Aken'ova et al who reported a prevalence of $6 \%$ for iron deficiency in adult patients with sickle cell disease in Ibadan, Nigeria. ${ }^{19}$ Iron deficiency may be more common in sickle cell anemia than is widely believed. ${ }^{14,20}$ Iron deficiency is thus more common than iron overload in patients with sickle cell disease, which is not consistent with the numerous reports of iron overload in patients with sickle cell disease. ${ }^{11-13}$ Major confounders in our study were the other causes of anemia not evaluated, including malaria, hookworm infestation, and folate/vitamin B12 deficiency, but unless associated with loss of iron they would not impact on the results.

\section{Conclusion}

The majority of patients with sickle cell disease have normal iron stores, mean serum ferritin is higher in men than in women, and iron deficiency is more common than iron overload in sickle cell anemia.

\section{Acknowledgment}

We are grateful to S Adeyoloja for performing the ferritin enzyme-linked immunosorbent assay.

\section{Disclosure}

The authors report no conflicts of interest in this work.

\section{References}

1. Sergent GR. Nomenclature and genetics of sickle cell disease. In: Textbook of Haematology on Sickle Cell Disease, 1st ed. New York, NY: Oxford University Press; 1985.

2. Isaacs WA, Hayhoe FG. Steroid hormones in sickle cell anemia. Nature. 1967;215:1139-1142.

3. Hoffbrand AV, Lewis SM, Tuddenham ED, et al, editors. Iron. Postgraduate Haematology, 4th ed. New York, NY: Oxford University Press; 2001.

4. Burhman E, Mentzer WB, Lubin BH. The influence of plasma bilirubin on zinc protoporphyrin measurement by a hematofluorimeter. $J \mathrm{Lab}$ Clin Med. 1978;91:710-716.

5. Koerper MA, Stempel DA, Dallman PR. Anemia in patients with juvenile rheumatoid arthritis. J Pediatr. 1978;92:930-933.

6. Stoltzfus R. Defining iron-deficiency anemia in public health terms: a time for reflection. $J$ Nutr. 2001;131:565S-567S.

7. Jurado RL. Iron, infections, and anemia of inflammation. Clin Infect Dis. 1997;25:888-895.

8. Brownell A, Lowson S, Bronzovic M. Serum ferritin concentrations in sickle cell crises. J Clin Pathol. 1986;39:253-255.

9. Erlandson ME, Walden B, Stern G, Hilgartner MW, Wehman J, Smith CH. Studies on congenital hemolytic syndromes, IV. Gastrointestinal absorption of iron. Blood. 1962;19:359-378.

10. O'Brien RT. Iron burden in sickle cell anemia. J Pediatr. 1978;92:579-582.

11. Oluboyede OA, Usang EA, Lukanbi FA, Ajayi OA. Evaluation of serum ferritin levels and other hematological parameters in a Nigerian population. J Natl Med Assoc. 1983;75:885-889.

12. Hussein MA, Davis LR, Laulicht M, Hoffbrand AV. Value of serum ferritin estimation in sickle cell anemia. Arch Dis Child. 1978;53: 319-321.

13. Brownell A, Lowson S, Bronzovic M. Serum ferritin concentrations in sickle cell crisis. J Clin Pathol. 1986;39:253-255.

14. Rao KRP, Patel AR, McGinns P, Patel MK. Iron stores in adults with sickle cell anemia. J Lab Clin Med. 1984;103:792-797.

15. Charache S, Bleecker ER, Bross DS. Effects of blood transfusion on exercise capacity in patients with sickle-cell anemia. Am J Med. 1983;74:757-764.

16. Lusher JM, Haglighat H, Khalifa AS. A prophylactic transfusion program for children with sickle cell anemia complicated by CNS infarction. Am J Hematol. 1976;1:265-273.

17. Green M, Hall RJC, Huntsman RG, Lawson A, Pearson TC, Wheeler PC. Sickle cell crisis treated by exchange transfusion. JAMA. 1975;231:948-950. 
18. Krafte-Jacobs B, Williams J, Soldin SJ. Plasma erythropoietin reference ranges in children. J Pediatr. 1995;126:601-603.

19. Aken'ova YA, Adeyefa I, Okunade M. Ferritin and serum iron levels in adult patients with sickle cell anaemia at Ibadan, Nigeria. Afr J Med Med Sci. 1997;26:39-41.
20. Davies S, Henthrorn J, Brozovic M. Iron deficiency in sickle cell anemia. J Clin Pathol. 1983;36:1012-1015.

Journal of Blood Medicine

\section{Publish your work in this journal}

The Journal of Blood Medicine is an international, peer-reviewed, open access, online journal publishing laboratory, experimental and clinical aspects of all topics pertaining to blood based medicine including but not limited to: Transfusion Medicine; Blood collection, Donor issues, Transmittable diseases, and Blood banking logistics; Immunohematology; Artificial and alternative
Dovepress

blood based therapeutics; Hematology; Biotechnology/nanotechnology of blood related medicine; Legal aspects of blood medicine; Historical perspectives. The manuscript management system is completely online and includes a very quick and fair peer-review system. Visit http://www.dovepress.com/ testimonials.php to read real quotes from published authors.

Submit your manuscript here: http://www.dovepress.com/Journal-of-blood-medicine-journal 